\title{
COMBINED INFLUENCE OF V AND Cr ON THE AlSi10MgMn ALLOY WITH A HIGH Fe LEVEL
}

\author{
VZAJEMNI VPLIV V IN Cr NA ZLITINO AlSi10MgMn Z VISOKO \\ VSEBNOSTJO Fe
}

\author{
Dana Bolibruchová, Mária Žihalová \\ Department of Technological Engineering, Faculty of Mechanical Engineering, University of Žilina, Univerzitná 8215/1, 01026 Žilina, \\ Slovakia \\ maria.zihalova@fstroj.uniza.sk
}

Prejem rokopisa - received: 2014-07-31; sprejem za objavo - accepted for publication: 2014-10-09

doi:10.17222/mit.2014.146

\begin{abstract}
Removing impurities from aluminium alloys increases the final cost of castings. The most common impurity in Al-Si based alloys is iron, whose removal is the main problem for secondary $\mathrm{Al}-\mathrm{Si}$ alloys. Several techniques of eliminating iron effects have been introduced, but the most common one is the use of iron "correctors" that change the morphology of iron-based intermetallic phases. The use of the correctors like $\mathrm{Co}$ and $\mathrm{Mn}$ is well described but other elements such $\mathrm{Ni}, \mathrm{Cr}$ and $\mathrm{V}$ need to be studied more extensively. In the present paper, the influence of $\mathrm{V}$ and the combined influence of $\mathrm{V}$ and $\mathrm{Cr}$ are analysed. The aim of the article is to determine the microstructure, the mechanical properties and the solidification behaviour of the AlSi10MgMn cast alloy with a high iron level treated with $\mathrm{V}$ and $\mathrm{Cr}$.

Keywords: AlSi10MgMn, iron correctors, combined effect, vanadium, chromium
\end{abstract}

Odstranjevanje nečistoč iz aluminijevih zlitin povečuje končne stroške pri ulitkih. Najbolj pogosta nečistoča v zlitinah na osnovi Al-Si je železo. Uvedenih je bilo več tehnik za odstranitev vpliva železa, vendar je najpogostejša uporaba "korektorjev" železa, ki spremenijo morfologijo intermetalnih faz na osnovi železa. Uporaba korektorjev, kot sta Co in Mn, je dobro opisana, pri drugih elementih, kot na primer $\mathrm{Ni}, \mathrm{Cr}$ in $\mathrm{V}$, pa so potrebne še dodatne raziskave. $\mathrm{V}$ članku je analiziran vpliv $\mathrm{V}$ in vzajemn vpliv $\mathrm{V}$ in Cr. Namen članka je določiti mikrostrukturo, mehanske lastnosti in vedenje pri strjevanju livarske zlitine AlSi10MgMn z visoko vsebnostjo železa in te zlitine, obdelane z V in Cr.

Ključne besede: AlSi10MgMn, korektorji železa, vzajemni vpliv, vanadij, krom

\section{INTRODUCTION}

Aluminium has been acquiring increasing significance over the past few decades due to its excellent properties and a diversified range of applications. ${ }^{1}$ Over the years, aluminium alloys have been specially developed to meet the increasing demands of today's industry. This development has resulted in the production of smaller and light-weight components that comply with property, environmental and other specifications. Recently, the appeal for recycling the resources has become more intensive with the increasing public awareness of the need to preserve the materials and energy and to protect the environment. However, the increasing use of recycled aluminium casting alloys requires a strict procedure of removing the harmful effects of impurity elements. ${ }^{2}$

The most common impurity in aluminium $\mathrm{Al}-\mathrm{Si}$ alloys is iron. Iron is highly soluble in liquid aluminium and its alloys, but it has a very low solubility in the solid state and so it tends to combine with other elements to form intermetallic-phase particles of various types. ${ }^{3-5}$ The morphologies of iron-containing intermetallics are often found to cause negative effects, where the plate-like phases, such as $\beta-\mathrm{Al}_{5} \mathrm{FeSi}$, are considered to be more harmful than the script-type phases, such as $\alpha-\mathrm{Al}_{15}(\mathrm{FeMn})_{3} \mathrm{Si}_{2} .{ }^{5}$

When $\mathrm{Fe}$ is present in excess of specified levels, various methods are available to reduce its harmful influence. The conventional method is to add some chemical "correctors" to change the morphology from the platelet $\beta-\mathrm{Al}_{5} \mathrm{FeSi}$ (a brittle form) to the globular or script forms (less brittle forms). The globular or script Fe-rich phases are considered not to lead to brittleness. Alternative methods of iron reduction are described in various references. ${ }^{6,7}$ Manganese is the most commonly used and the least expensive element for Fe neutralisation in Al-Si alloys. ${ }^{2}$ If an iron amount exceeds a value of the mass fraction $w=0.45 \%$, the recommended addition of Mn should not be lower than half of the iron amount; ${ }^{7}$ however, script-like particles containing Mn are still observed at the Mn-to-Fe ratio of $0.17 .{ }^{8}$ Other iron correctors also include $\mathrm{Co}, \mathrm{Cr}$, $\mathrm{Mo}, \mathrm{Ni}, \mathrm{V}$ and Be. ${ }^{3,4,6,7} \mathrm{Cr}$ improves the strength at indoor and higher temperatures and mildly deteriorates the elongation. The presence of $\mathrm{Cr}$ phases $(\mathrm{CrFe})_{4} \mathrm{Si}_{4} \mathrm{Al}_{13}$ and $(\mathrm{CrFe})_{5} \mathrm{Si}_{8} \mathrm{Al}_{2}$ can increases the brittleness. ${ }^{9} 10$ Vanadium refines the grains of aluminium alloys. Together with $\mathrm{Ti}$ and Mo, it increases the hot-cracking resistance and decreases the porosity. ${ }^{9}$ The influence of $\mathrm{V}$ occurs with an amount of 0.05-0.15 
Table 1: Chemical composition of AlSi10MgMn alloy

Tabela 1: Kemijska sestava zlitine AlSi10MgMn

\begin{tabular}{|c|c|c|c|c|c|c|c|c|c|c|}
\hline Element & $\mathrm{Si}$ & $\mathrm{Mg}$ & $\mathrm{Mn}$ & $\mathrm{Fe}$ & $\mathrm{Ti}$ & $\mathrm{Zn}$ & $\mathrm{Cu}$ & $\mathrm{V}$ & $\mathrm{Cr}$ & $\mathrm{Al}$ \\
\hline Amount $(w / \%)$ & 10.220 & 0.277 & 0.108 & 0.448 & 0.046 & 0.029 & 0.047 & 0.010 & 0.006 & balance \\
\hline
\end{tabular}

$\%$ of the melt mass. $\mathrm{V}$ reduces the length of $\beta$-phase platelets $\mathrm{Al}_{5} \mathrm{FeSi}$ and, together with $\mathrm{Ni}$ and $\mathrm{T}$, it has a significant influence on improving the mechanical properties $\left(R_{\mathrm{m}}\right.$ and $\left.A_{5}\right)$. Similarly to $\mathrm{Fe}$ and $\mathrm{Co}$, vanadium has a negative influence on the fluidity of Al-Si alloys. ${ }^{9}$ There is also a significant beneficial influence of vanadium on the hardness. ${ }^{10}$

Until now a large number of experiments focusing on the influence of individual iron correctors have been performed ${ }^{9,10}$ but few papers about a combined influence of iron correctors have been published. Petrík et al. ${ }^{11}$ evaluated the properties of an Al-Si alloy containing Fe, $\mathrm{Ni}$ and Mn. Kumari et al. ${ }^{2}$ investigated the effects of individual and combined additions of $\mathrm{Be}, \mathrm{Mn}, \mathrm{Ca}$ and $\mathrm{Sr}$ on the solidification behaviour of the structure and mechanical properties of the $\mathrm{AlSi} 7 \mathrm{Mg} 0.3 \mathrm{Fe} 0.8$ alloy. These papers refer to the beneficial influences of the combined additions of the selected iron correctors; however, there is very little evidence of an influence of combined vanadium-and-chromium additions on $\mathrm{Al}-\mathrm{Si}$ alloys.
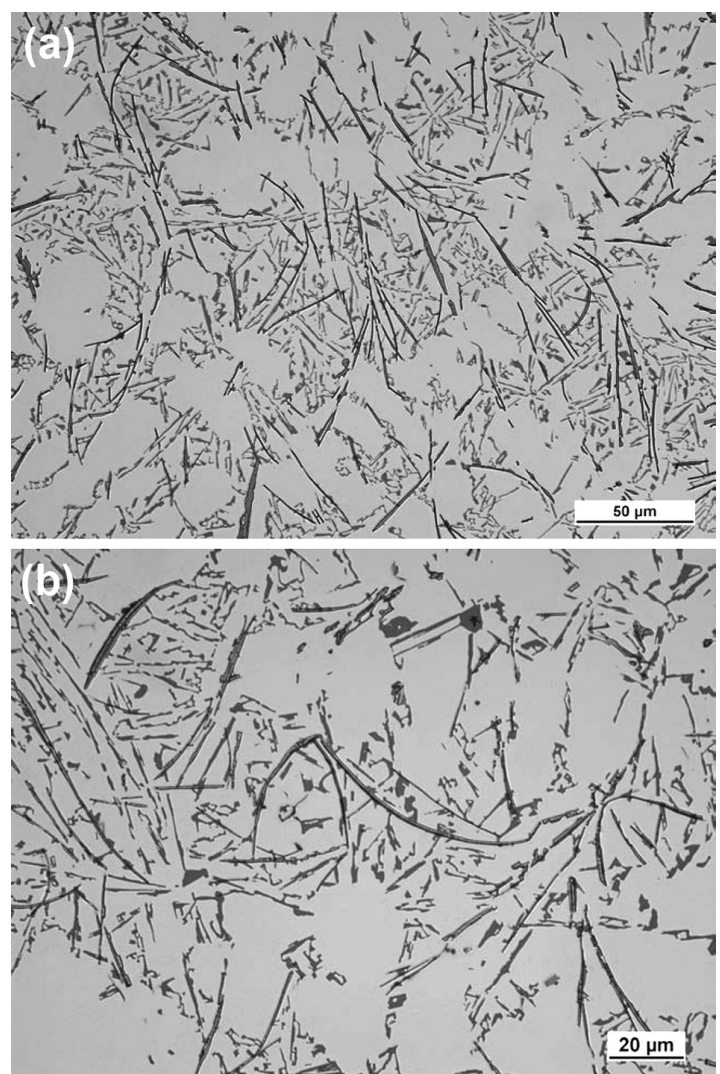

Figure 1: a) AlSi10MgMn $+w(\mathrm{Fe}) 1 \%$, b) detail of Fe phases, etched in $20 \mathrm{~mL} \mathrm{H}_{2} \mathrm{SO}_{4}+100 \mathrm{~mL} \mathrm{H} \mathrm{H}_{2} \mathrm{O}$

Slika 1: a) AlSi10MgMn + w(Fe) $1 \%$, b) detajl Fe-faz, jedkano v 20 $\mathrm{mL} \mathrm{H}_{2} \mathrm{SO}_{4}+100 \mathrm{~mL} \mathrm{H} \mathrm{H}_{2} \mathrm{O}$
In this paper the influences of vanadium and of an addition combining $\mathrm{V}$ and $\mathrm{Cr}$ are analysed in the AlSi10MgMn alloy with an elevated iron amount.

\section{MATERIALS AND METHODOLOGY}

Aluminium alloy AlSi10MgMn was used as the experimental material. The chemical composition of the used alloy is presented in Table 1. In the first stage of the experiments, the commercial AlSi10MgMn alloy was alloyed with iron. Iron was added in the amount of $40000 \mu \mathrm{g} / \mathrm{g}$ using the AlFe10 master alloy. After obtaining the alloy with a high $\mathrm{Fe}$ mass content $(1 \%$ of $\mathrm{Fe}), \mathrm{V}$ and $\mathrm{Cr}$ were added. Vanadium was added in the mass fraction of $0.2 \%$ and the combined addition of $\mathrm{V}$ and $\mathrm{Cr}$ included $0.2 \%$ of $\mathrm{V}$ and 0.5 and $1 \%$ of $\mathrm{Cr}$. The required amounts of $\mathrm{V}$ and $\mathrm{Cr}$ were added as the AlV10 and AlCr20 master alloys. For each experiment, the alloy was melted in a graphite crucible using an electric-resistance furnace. The melts were not further modified, grain refined or purified. The melts were poured into perma-
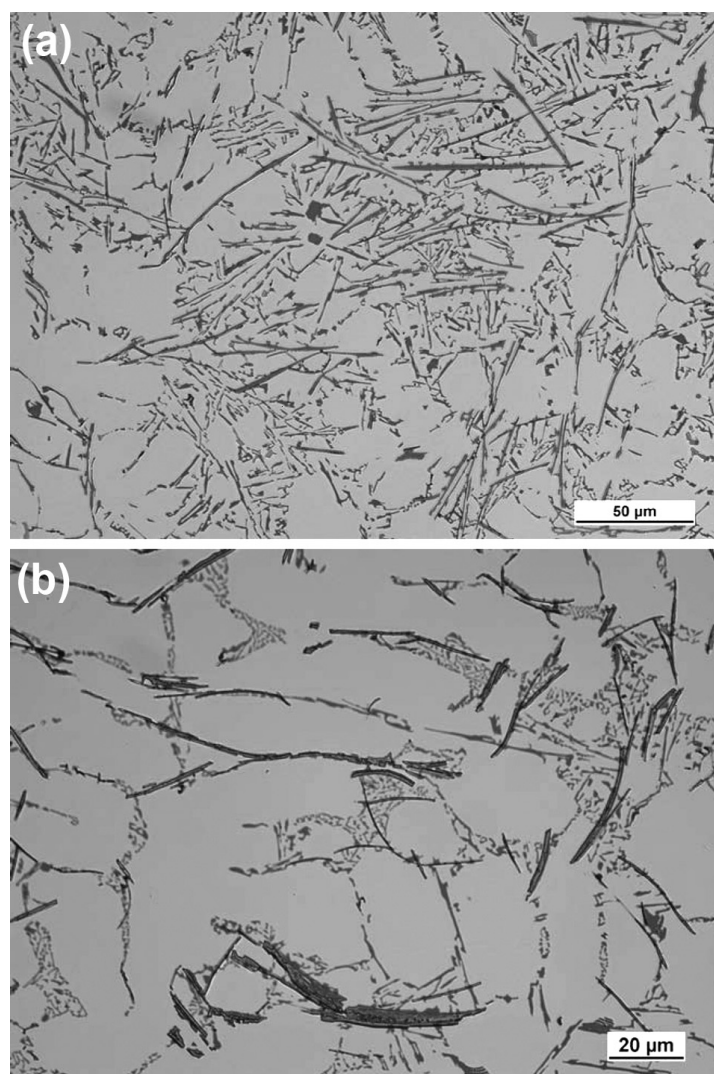

Figure 2: a) AlSi10MgMnFe $+w(\mathrm{~V}) 0.2 \%$, b) detail of $\mathrm{Fe}$ phases, etched in $20 \mathrm{~mL} \mathrm{H}_{2} \mathrm{SO}_{4}+100 \mathrm{~mL} \mathrm{H}_{2} \mathrm{O}$

Slika 2: a) AlSi10MgMnFe + $w(\mathrm{~V}) 0,2 \%$, b) detajl Fe-faz, jedkano v $20 \mathrm{~mL} \mathrm{H}_{2} \mathrm{SO}_{4}+100 \mathrm{~mL} \mathrm{H} \mathrm{H}_{2} \mathrm{O}$ 
nent moulds preheated to $200{ }^{\circ} \mathrm{C}$ after reaching a temperature of $(760 \pm 5){ }^{\circ} \mathrm{C}$. From the poured castings, specimens for the tensile testing, hardness testing and microstructure evaluation were prepared. The solidification behaviour of the melts was analysed with the measuring equipment containing $\mathrm{NiCr}-\mathrm{Ni}$ thermocouples.

\section{RESULTS}

\subsection{Microstructure}

Figure 1 shows the typical microstructure of the AlSi10MgMn alloy with an addition of a mass fraction $1 \%$ of Fe. It can be seen that platelets of the $\beta-\mathrm{Al}_{5} \mathrm{FeSi}$ phases are present in the interdendritic regions as well as precipitated along with the eutectic $\mathrm{Si}$. The needles of the $\beta-\mathrm{Al}_{5} \mathrm{FeSi}$ phase are evenly dispersed in the alloy and only small amounts of script-like particles are present.

The microstructure of the alloy with the $\mathrm{V}$ addition is shown in Figure 2. The needle-like phases present in the microstructure were of a different colour after the etching compared to alloy containing $1 \%$ of Fe. The distribution and dimensions of the needles are similar to those of the alloy without the vanadium addition.

The combined addition of $\mathrm{V}$ and $\mathrm{Cr}$ caused the occurrence of sludge phases in the alloys' microstructures (Figures 3 and 4). In the alloy with a higher $\mathrm{Cr}$
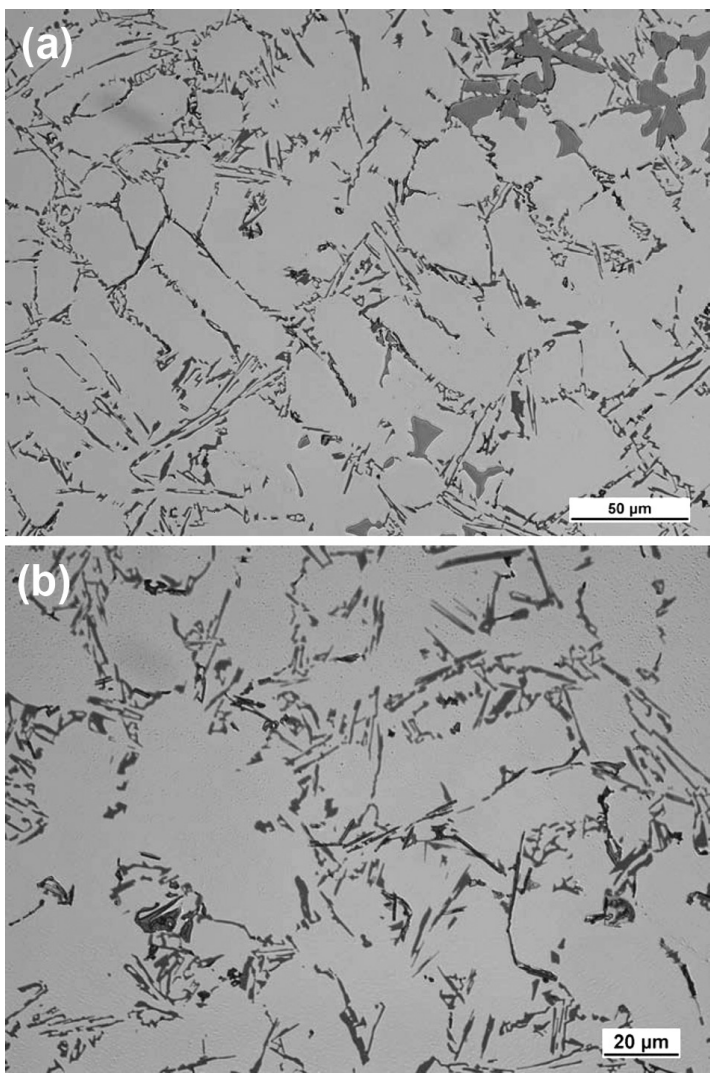

Figure 3: a) AlSi10MgMnFe $+w(\mathrm{~V}) 0.2 \%+w(\mathrm{Cr}) 0.5 \%$, b) detail of Fe phases, etched in $20 \mathrm{~mL} \mathrm{H}_{2} \mathrm{SO}_{4}+100 \mathrm{~mL} \mathrm{H}_{2} \mathrm{O}$

Slika 3: a) AlSi10MgMnFe $+w(\mathrm{~V}) 0,2 \%+w(\mathrm{Cr}) 0,5 \%$, b) detajl Fe-faz, jedkano v $20 \mathrm{~mL} \mathrm{H}_{2} \mathrm{SO}_{4}+100 \mathrm{~mL} \mathrm{H}_{2} \mathrm{O}$
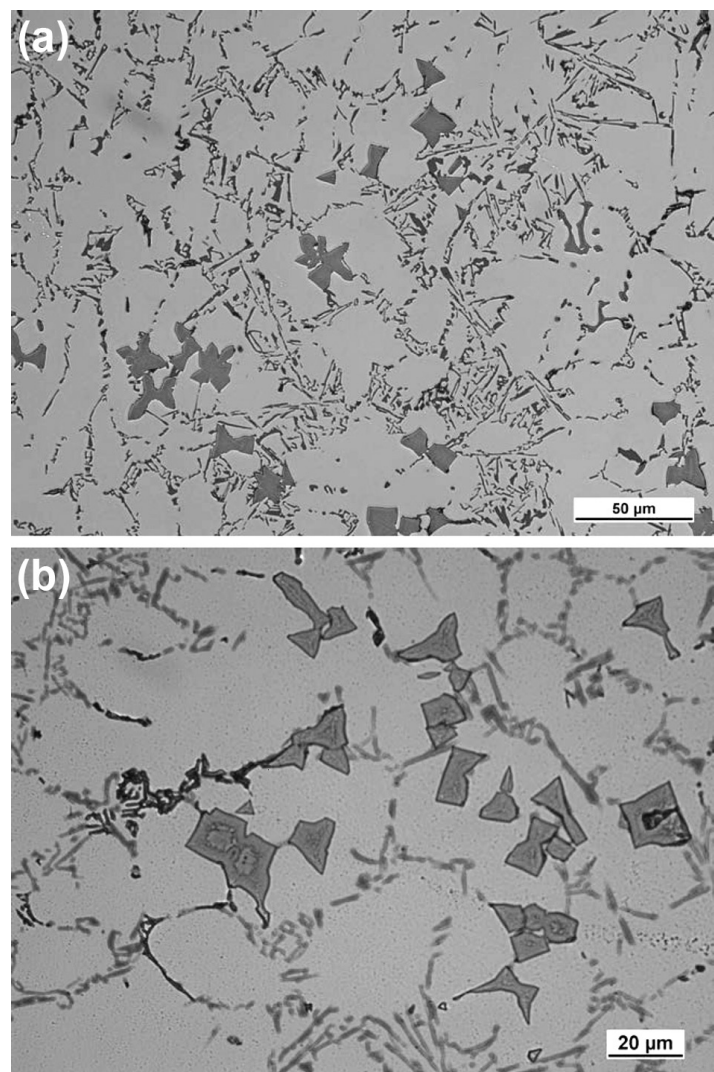

Figure 4: a) AlSi10MgMnFe $+w(\mathrm{~V}) 0.2 \%+w(\mathrm{Cr}) 1.0 \%$, b) detail of Fe phases, etched in $20 \mathrm{~mL} \mathrm{H}_{2} \mathrm{SO}_{4}+100 \mathrm{~mL} \mathrm{H}_{2} \mathrm{O}$

Slika 4: a) $\mathrm{AlSi} 10 \mathrm{MgMnFe}+w(\mathrm{~V}) 0,2 \%+w(\mathrm{Cr}) 1,0 \%$, b) detaj1 Fe-faz, jedkano v $20 \mathrm{~mL} \mathrm{H}_{2} \mathrm{SO}_{4}+100 \mathrm{~mL} \mathrm{H}_{2} \mathrm{O}$

level, a higher amount of sludge phases is present as the sludge-phase formation is mostly influenced by the $\mathrm{Cr}$ level in the alloy. ${ }^{7}$ Iron-based intermetallic phases are smaller after both additions of $\mathrm{Cr}(w=0.5 \%$ and $1.0 \%)$.

\subsection{Mechanical properties}

An examination of the ultimate tensile strength (UTS) and elongation of the alloys was performed in line with the EN ISO 6892-1 standard. The ultimate tensile strength and elongation of the alloys are shown in Figure 5. The addition of $\mathrm{Fe}$ to the commercial AlSi10MgMn alloy caused a decrease in the UTS and elongation (sample No. 2). The highest improvement in both UTS and elongation was observed after the vanadium addition $(w=0.2 \%)$. The combined addition of $\mathrm{V}$ and $\mathrm{Cr}$ decreased the alloy's tensile properties. The tensile strength of the alloy with the combined addition is even lower than that of the alloy containing a high iron amount. The same is true of the elongation in the case of the addition of $\mathrm{V}$ and $\mathrm{Cr}$ in the mass fractions of $0.2 \%$ and $0.5 \%$. The hardness of the alloys was evaluated with the Brinell hardness-measuring method in line with the EN ISO 6506-1 standard. In Figure 6 it can be seen that after the additions of all the investigated elements, Brinell hardness increased. The most significant increase 


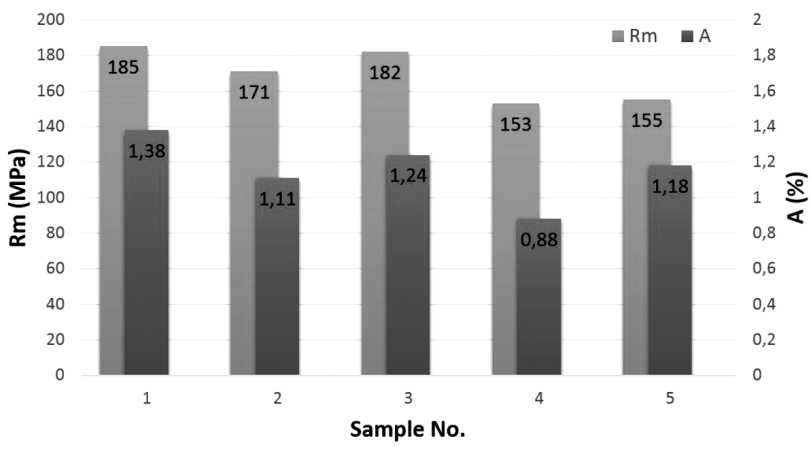

Figure 5: Tensile strength and elongation of AlSi10MgMn alloy: sample No. 1 - commercial AlSi10MgMn alloy, sample No. 2 $\mathrm{AlSi} 10 \mathrm{MgMn}+w(\mathrm{Fe}) 1 \%$, sample No. $3-\mathrm{AlSi10MgMnFe}+w(\mathrm{~V})$ $0.2 \%$, sample No. $4-\mathrm{AlSi} 10 \mathrm{MgMnFe}+w(\mathrm{~V}) 0.2 \%+w(\mathrm{Cr}) 0.5 \%$ and sample No. 5 - AlSi10MgMnFe $+w(\mathrm{~V}) 0.2 \%+w(\mathrm{Cr}) 1.0 \%$

Slika 5: Natezna trdnost in raztezek zlitine AlSi10MgMn: vzorec št. 1 - komercialna zlitina AlSi10MgMn, vzorec št. 2 - AlSi10MgMn + $w(\mathrm{Fe}) 1 \%$, vzorec št. $3-\mathrm{AlSi} 10 \mathrm{MgMnFe}+w(\mathrm{~V}) 0,2 \%$, vzorec št. 4 - AlSi10MgMnFe $+w(\mathrm{~V}) 0,2 \%+w(\mathrm{Cr}) 0,5 \%$ in vzorec št. $5-$ AlSi10MgMnFe $+w(\mathrm{~V}) 0,2 \%+w(\mathrm{Cr}) 1,0 \%$

(42\%) in the alloy's hardness occurred for the V-alloyed sample.

\subsection{Thermal analysis}

A cylindrical sample with a thermocouple placed in the middle of the casting was used for obtaining the thermal curve. Figures $\mathbf{7}$ to $\mathbf{1 0}$ show the cooling curves and their first derivatives and Table 2 lists the alloys, thermal arrests and phases formed in the analysed alloys. The first derivative is a measure of the instantaneous cooling rate along the cooling curve and is used to indicate the presence of minor slope changes on the curves. ${ }^{2}$ Figure 7 shows the first thermal-arrest point of the AlSi10MgMn alloy with the mass fraction $1.0 \%$ of Fe at

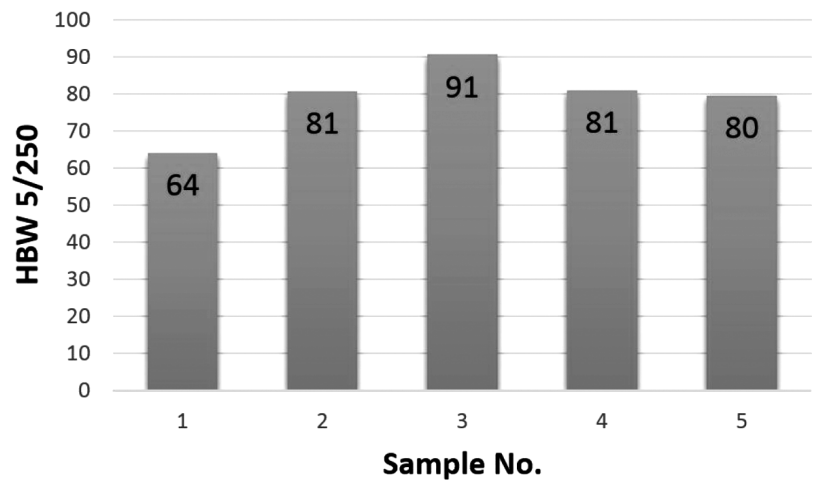

Figure 6: Brinell hardness of AlSi10MgMn alloy: sample No. 1 commercial AlSi10MgMn alloy, sample No. 2 - AlSi10MgMn + $w(\mathrm{Fe}) 1 \%$, sample No. $3-\mathrm{AlSi} 10 \mathrm{MgMnFe}+w(\mathrm{~V}) 0.2 \%$, sample No. $4-\mathrm{AlSi} 10 \mathrm{MgMnFe}+w(\mathrm{~V}) 0.2 \%+w(\mathrm{Cr}) 0.5 \%$ and sample No. $5-$ AlSi10MgMnFe $+w(\mathrm{~V}) 0.2 \%+w(\mathrm{Cr}) 1.0 \%$

Slika 6: Brinellova trdota zlitine AlSi10MgMn: vzorec št. 1 komercialna zlitina AlSi10MgMn, vzorec št. 2 - AlSi10MgMn + $w(\mathrm{Fe}) 1 \%$, vzorec št. $3-\mathrm{AlSi} 10 \mathrm{MgMnFe}+w(\mathrm{~V}) 0,2 \%$, vzorec št. $4-$ $\mathrm{A} 1 \mathrm{Si} 10 \mathrm{MgMnFe}+w(\mathrm{~V}) 0,2 \%+w(\mathrm{Cr}) 0,5 \%$ in vzorec št. $5-$ $\mathrm{AlSi} 10 \mathrm{MgMnFe}+w(\mathrm{~V}) 0,2 \%+w(\mathrm{Cr}) 1,0 \%$
$591.2{ }^{\circ} \mathrm{C}$, where the formation and growth of $\mathrm{Al}$ nuclei occur. After this arrest, the temperature of the solidifying alloy continues to decrease. The second thermal arrest occurs at $575{ }^{\circ} \mathrm{C}$. This is caused by the latent heat of fusion of the iron intermetallic phases. The last thermalarrest point occurs at $566.7{ }^{\circ} \mathrm{C}$, corresponding to the eutectic-Si formation and growth. The cooling curve does not indicate the thermal arrest at the temperature corresponding with the formation of the $\mathrm{Mg}_{2} \mathrm{Si}$ phase. It might have been caused by a very low $\mathrm{Mg}$ level in the measuring place and solidification conditions that do not result in the formation of the $\mathrm{Mg}_{2} \mathrm{Si}$ phase. The thermal arrests corresponding with the primary $\alpha$-Al after the additions of $\mathrm{V}$ and also $\mathrm{V}$ with $\mathrm{Cr}$ occur at higher temperatures. The eutectic temperature after the combined addition of $\mathrm{V}$ and $\mathrm{Cr}$ decreased compared to that of the

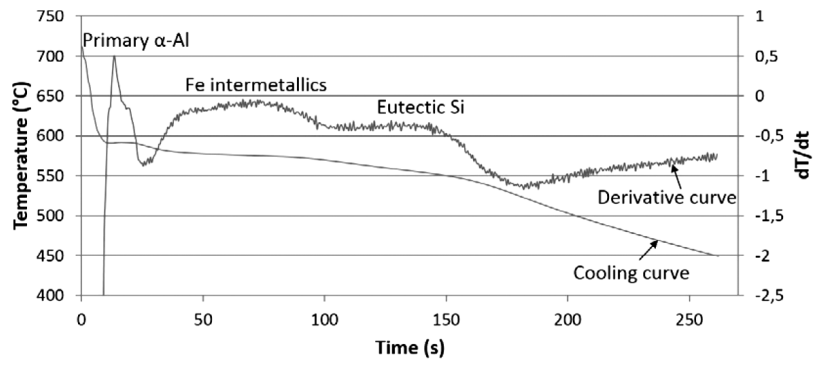

Figure 7: Cooling curve and its first derivative of AlSi10MgMn alloy with $w(\mathrm{Fe}) 1.0 \%$

Slika 7: Ohlajevalna krivulja in njen prvi odvod zlitine AlSi10MgMn $\mathrm{z} w(\mathrm{Fe}) 1,0 \%$

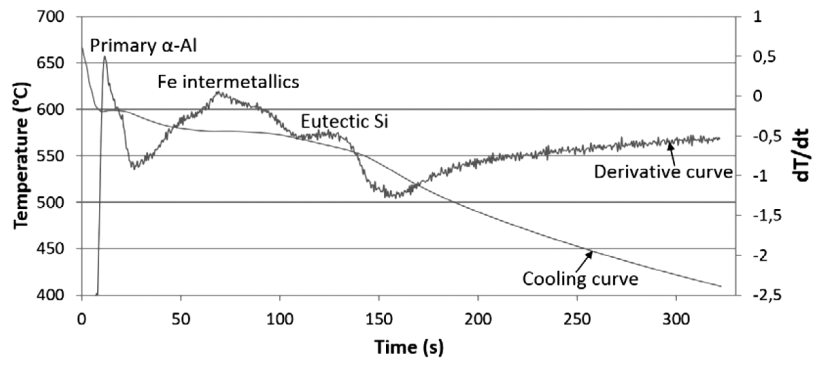

Figure 8: Cooling curve and its first derivative of AlSi10MgMnFe alloy with $w(\mathrm{~V}) 0.2 \%$

Slika 8: Ohlajevalna krivulja in njen prvi odvod zlitine AlSi10MgMnFe z $w($ V) $0,2 \%$

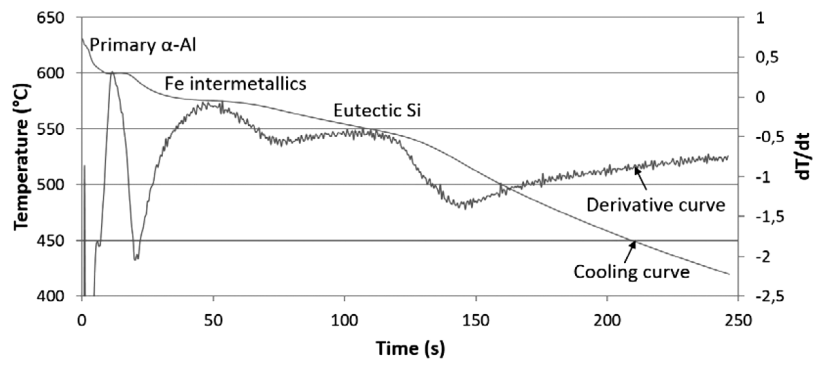

Figure 9: Cooling curve and its first derivative of AlSi10MgMnFe alloy with $w(\mathrm{~V}) 0.2 \%$ and $w(\mathrm{Cr}) 0.5 \%$

Slika 9: Ohlajevalna krivulja in njen prvi odvod zlitine AlSi10MgMnFe $\mathrm{z} w(\mathrm{~V}) 0,2 \%$ in $w(\mathrm{Cr}) 0,5 \%$ 


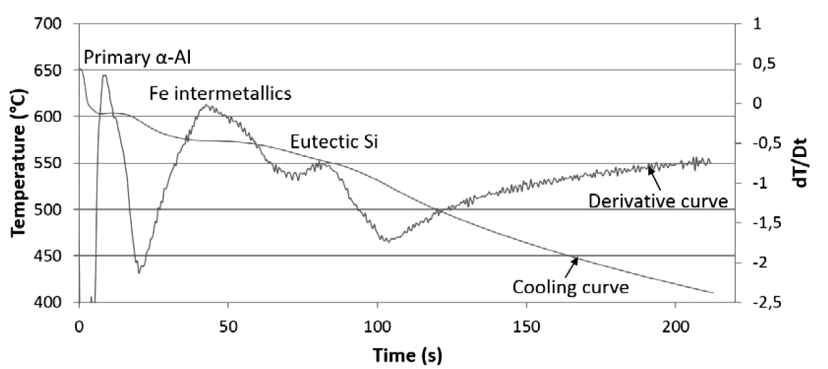

Figure 10: Cooling curve and its first derivative of AlSi10MgMnFe alloy with $w(\mathrm{~V}) 0.2 \%$ and $w(\mathrm{Cr}) 1.0 \%$

Slika 10: Ohlajevalna krivulja in njen prvi odvod zlitine AlSi10MgMnFe z $w(\mathrm{~V}) 0,2 \%$ in $w(\mathrm{Cr}) 1,0 \%$

alloy with the Fe addition and the difference between the eutectic temperatures of the alloy containing mass fractions $0.5 \%$ and $1.0 \%$ of $\mathrm{Cr}$ and the alloy without $\mathrm{V}$ and $\mathrm{Cr}$ is $17.9^{\circ} \mathrm{C}$ and $14{ }^{\circ} \mathrm{C}$, respectively. This leads to the formation of a finer eutectic Si compared to the alloy with the iron addition.

Table 2: Thermal arrests and phases formed in AlSi10MgMn alloy with a high iron level without and with $\mathrm{V}$ and $\mathrm{Cr}$ additions

Tabela 2: Toplotni zastoji in faze, ki nastajajo v AlSi10MgMn zlitini z visoko vsebnostjo železa ter brez dodatka $\mathrm{V}$ in $\mathrm{Cr}$ ali z njima

\begin{tabular}{|c|c|c|}
\hline Alloy & $\begin{array}{c}\text { Thermal arrest } \\
\left(\text { Temperature }\left({ }^{\circ} \mathrm{C}\right)\right)\end{array}$ & Phases formed \\
\hline AlSi10MgMn + & 591.2 & Primary $\alpha$-Al \\
$w(\mathrm{Fe}) 1.0 \%$ & 575.0 & Iron intermetallics \\
& 566.7 & Eutectic Si \\
\hline AlSi10MgMnFe + & 597.7 & Primary $\alpha$-Al \\
$w(\mathrm{~V}) 0.2 \%$ & 576.0 & Iron intermetallics \\
& 563.2 & Eutectic Si \\
\hline AlSi10MgMnFe + & 599.4 & Primary $\alpha$-Al \\
$w(\mathrm{~V}) 0.2 \%+w(\mathrm{Cr})$ & 575.5 & Iron intermetallics \\
$0.5 \%$ & 548.8 & Eutectic Si \\
\hline AlSi10MgMnFe + & 603.4 & Primary $\alpha$-Al \\
$w(\mathrm{~V}) 0.2 \%+w(\mathrm{Cr})$ & 574.1 & Iron intermetallics \\
$1.0 \%$ & 552.7 & Eutectic Si \\
\hline
\end{tabular}

\section{DISCUSSIONS}

The microstructure of the AlSi10MgMn alloy after the iron addition in the mass fractions of $1.0 \%$ contains a large amount of iron-based intermetallic phases, mostly in the form of platelets. After the addition of $w(\mathrm{~V})=0.2$ $\%$, the platelet-like particles were still present but after the same etching technique as used with the iron-treated alloy, the needles obtained a different colour. This might have been due to a different chemical composition of the iron-based platelets. The combined addition of $\mathrm{V}$ and $\mathrm{Cr}$ caused the formation of sludge phases in the alloy. As the size and amount of the sludge phases are mostly influenced by $\mathrm{Cr}$, more of them were observed after the addition of $\mathrm{V}$ and $\mathrm{Cr}$ in the mass fractions of $0.2 \%$ and $1.0 \%$, respectively.

The formations of different intermetallic phases were reflected on the alloy's mechanical properties. The UTS of the alloy after the Fe addition decreased compared to the commercial AlSi10MgMn alloy. The decrease in the UTS is connected with a higher number of the brittle needle-like intermetallics in the iron-treated alloy. The addition of $\mathrm{V}(w=0.2 \%)$ improved the tensile strength of the iron-polluted alloy, but its value was still lower than for the commercial alloy. Vanadium is known as a grain-refining element and this characteristic might have been one of the reasons for the tensile-strength improvement. Also, it is possible that the chemical interaction between the iron-based phases and vanadium caused the change in the phase colour after the etching, leading to a decrease in the deleterious effect of such phases on the UTS. The combined addition of $\mathrm{V}$ and $\mathrm{Cr}$ in both mass fractions $(0.2 \% \mathrm{~V}+0.5 \% \mathrm{Cr}$ and $0.2 \% \mathrm{~V}+1.0 \% \mathrm{Cr})$ leads to a significant decrease in the alloy's UTS. The reason for the decreased tensile properties is the formation of hard and brittle sludge phases. These phases are brittle and cannot withstand the same stress as the ductile aluminium matrix.

The elongation of the alloys was influenced similarly by the analysed elements. The highest elongation was found for the commercial alloy $(1.38 \%)$, followed by the alloy treated with iron and vanadium $(1.24 \%)$. Brinell hardness was positively influenced by every used element. The highest Brinell hardness was found for the alloy containing $\mathrm{Fe}(w=1.0 \%)$ and $\mathrm{V}(w=0.2 \%)$. The reason for the increase in the hardness value after the addition of iron is probably a higher amount of iron intermetallic phases with a high value of microhardness. The same effect on Brinell hardness might have occurred due to the presence of sludge phases after the combined addition of $\mathrm{V}$ and $\mathrm{Cr}$. The microhardness of the sludge phases can reach $800-1000 \mathrm{HV}^{7}$ while the aluminiummatrix microhardness is only $60-100 \mathrm{HV}$. The increase in the hardness after the $\mathrm{V}$ addition might have been caused by a high number of iron intermetallics and also by the strengthening of the aluminium matrix due to dissolved vanadium.

The thermal analysis of the alloys did not show any significant differences between the analysed alloys. It was found that the thermal arrest of the primary Al formation occurs at higher temperatures after the addition of $\mathrm{V}$ and $\mathrm{Cr}$ compared to the alloy containing the mass fraction $1.0 \%$ of Fe.

\section{CONCLUSION}

Several conclusions can be drawn from the obtained results of the individual and combined effects of $\mathrm{V}$ and $\mathrm{Cr}$ on the AlSi10MgMn alloy with a high iron level:

- The iron addition $(w=1.0 \%)$ to the commercial AlSi10MgMn alloy caused the formation of a high amount of iron-based platelet particles. The tensile properties (UTS and elongation) were decreased but the hardness increased. 
- The addition of $\mathrm{V}(w=0.2 \%)$ to the iron-containing alloy led to changes in the mechanical properties. The UTS and elongation were positively affected and the measured values almost reached the values of the commercial alloy. $\mathrm{V}$ also caused Brinell hardness to increase to the highest value (91 HBW) compared to the other analysed alloys.

- The combined influence of $\mathrm{V}$ and $\mathrm{Cr}$ led to the formation of sludge phases. These phases decreased the mechanical properties compared to the vanadiumtreated alloy. The UTS and Brinell hardness were almost the same at the chromium levels of $w=(0.5$ and 1.0$) \%$. The elongation of the samples was the lowest with the combined $\mathrm{V}$ and $\mathrm{Cr}$ addition of the mass fractions $0.2 \%$ and $0.5 \%$, respectively.

- The thermal analysis showed that alloying elements $\mathrm{V}$ and $\mathrm{Cr}$ do not have a significant influence on the solidification behaviour of the AlSi10MgMn alloy with a high iron level.

- The best combination of the mechanical and foundry properties was obtained with the vanadium addition in the mass fraction of $0.2 \%$.

\section{REFERENCES}

${ }^{1}$ E. Tillová, M. Chalupová, L. Hurtalová, Evolution of Phases in a Recycled Al-Si Cast Alloy During Solution Treatment, In: V. Kazmiruk (ed.), Scanning Electron Microscopy, chapter 21, Intech, 2012, 411-438, doi:10.5772/1973

${ }^{2}$ S. S. S. Kumari, R. M. Pillai, T. P. D. Rajan, B. C. Pai, Materials Science and Engineering A, 460-461 (2007), 561-573, doi:10.1016/ j.msea.2007.01.082

${ }^{3}$ J. A. Taylor, The Effect of Iron in Al-Si Casting Alloys, 35th Australian Foundry Institute National Conference, Adelaide, South Australia, 2004, 148-157

${ }^{4}$ J. A. Taylor, Procedia Materials Science, 1 (2012), 19-33, doi:10.1016/j.mspro.2012.06.004

${ }^{5}$ C. M. Dinnis, J. A. Taylor, A. K. Dahle, Scripta Materialia, 53 (2005), 955-958, doi:10.1016/j.scriptamat.2005.06.028

${ }^{6}$ X. Cao, J. Campbell, Materials Transactions, 47 (2006) 5, 1303-1312, doi:10.2320/matertrans.47.1303

${ }^{7}$ E. Tillová, M. Chalupová, Structural analysis of Al-Si cast alloys, $1^{\text {st }}$ ed., EDIS, Žilina 2009, 191 (in Slovak)

${ }^{8}$ X. Cao, J. Campbell, Metallurgical and Materials Transactions A, 35 (2004), 1425-1435, doi:10.1007/s11661-004-0251-0

${ }^{9}$ J. Petrík, M. Horvath, Annals of Faculty Engineering Hunedoara International Journal of Engineering, (2011), 401-405

${ }^{10}$ P. Szarvasy, J. Petrík, V. Špet'uch, Slévarenství, 53 (2005) 11-12, 521-524 (in Slovak)

${ }^{11}$ J. Petrík, P. Szarvasy, V. Špet'uch, Acta Metallurgica Slovaca, 10 (2004), 73-79 